\title{
Biofuel production using food
}

\author{
David Pimentel • Michael Burgess
}

Received: 19 November 2013/ Accepted: 20 November 2013/Published online: 6 December 2013

(C) Springer Science+Business Media Dordrecht 2013

Most of the transport systems of the developed world run on liquid fuels produced from petroleum. Global shortages of these liquid fuels, both current and anticipated, have led corporate and political leaders throughout the developed world to investigate and develop liquid fuels from food crops, mainly corn, palm oil, soybean, canola and sugarcane. Liquid fuels made from these foods, heavily subsidized by national governments, are being promoted to partially replace liquid fossil fuels. The United States has legislatively mandated (the Renewable Fuels Standards legislation enacted in 2007) that a certain portion of the overall corn and soybean crops annually be used to produce liquid biofuels. Emissions mandates and subsidies have been enacted by European countries as well to promote the production of liquid biofuels. These European emission standards and subsidies have in turn caused corporations involved in biodiesel production from palm oil to encourage the conversion of "unproductive forestlands" by governments of several tropical developing countries into plantations of oil palms to produce biodiesel stock for primarily European countries while reducing biodiversity, sustainable subsistence farming and increasing unemployment, and reducing the variety of foods available to most people in these regions. These governmental actions have raised commodity prices for all the food crops being used to make liquid biofuels as well as raising commodity prices of crops that can replace these biofuel stock commodities, which raises food prices for rich and poor alike. On top of which the energy inputs necessary to produce biodiesel from palm oil are $8 \%$ more than the energy obtained from palm oil biodiesel, which means at present, biodiesel production from palm oil is simply unsustainable in the absence of fossil fuels. Rapeseed and canola are the other two cultivated sources of oil for biodiesel production in Europe but the energy yield of the biodiesel obtained from these two oil seeds is $58 \%$ less than the energy, almost always from fossil fuels, needed to produce, transport, process these crops, and distribute the biodiesel. While rapeseed is not a food crop, growing rapeseed on land that could support crops makes its cultivation for biofuels a waste of good agricultural land while growing rapeseed on marginal land has been found by at least one

D. Pimentel $(\bowtie) \cdot$ M. Burgess

Cornell University, Ithaca, NY, USA

e-mail:dp18@cornell.edu 
study done in the Campania region of Italy to be economically, energetically, and environmentally unacceptable (Pimentel 2012).

Brazil produces ethanol from sugarcane, and the energy output of the ethanol produced is over 2 times the energy inputs necessary to grow, harvest, transport, process the sugarcane into ethanol, and then distribute the finished ethanol. While this pales in comparison with the energy output from a conventional oil field of over 20 times the energy inputs necessary for production, processing, and distribution, ethanol from sugarcane is perhaps at this time the only liquid biofuel that can be economically produced; however, the indirect costs of soil erosion, pesticide, and fertilizer pollution of ground and surface waters, the displacement of other crops, and the removal of rainforest and savannah due to increased areas being used for sugarcane production may make this biofuel unsustainable in the long run. At this time, Brazil can fuel most of its motor vehicles with ethanol simply because Brazil only consumes $9 \%$ of the US consumption of petroleum (Pimentel and Patzek 2008a).

Corn and soybean are the two predominant fuel stocks for bioethanol and biodiesel production, respectively, in the United States. Both are row crops sometimes grown in rotation with each other, sometimes grown in monoculture and as such expose soil to more erosion than practically any other crops grown in the United States. More herbicides and insecticides are applied to corn and soybean than any other field crops. The heavy use of nitrogen fertilizer on corn and the exposed soil between corn rows results in a great deal of nitrogen as well as other plant nutrients being eroded along with soil off croplands and into waterways. The nitrogen fertilizer requirement for corn production in the US Corn Belt is responsible for the Gulf of Mexico "dead zone"-areas of depleted dissolved oxygen due to algal blooms fertilized by high levels of dissolved nitrogen, when the blooms die off, and the oxygen from the surrounding water is consumed by decomposers, resulting in "dead zones." Pesticides used in the production of soybean and corn also move with water runoff into streams, rivers, and lakes contaminating drinking water and aquatic and marine life. When taking into account all energy inputs needed to produce corn and soybean and then to convert the corn grain and soybean into bioethanol and biodiesel, respectively, $46 \%$ more energy (fossil fuel energy) is expended to produce bioethanol from corn than is obtained from the bioethanol while for biodiesel from soybean oil, $53 \%$ more energy (again, fossil fuel energy) is expended than is obtained from the biodiesel fuel produced. Neither bioethanol from corn nor biodiesel from soybean is sustainable at present (Pimentel and Patzek 2008b).

All the above begs the questions-is biofuel production from foods energetically, environmentally, or even economically sustainable?-is biofuel production from foods ethical when $66 \%$ of the world's population is micronutrient malnourished and almost a billion are protein/caloric starved? he premise that either bioethanol or biodiesel could ever replace a significant portion of liquid fuel from petroleum is pure fantasy. The notion that biofuels can replace fossil liquid fuels is fantasy is supported by the fact that the US population annually uses 3 times the energy than is fixed photosynthetically by ALL plants growing in the United States.

\section{References}

Pimentel, D. (2012). Global economic and environmental aspects of biofuels. Boca Raton: CRC Press A Taylor and Francis Group. 
Pimentel, D., \& Patzek, T. (2008a). Ethanol production: Energy and economic issues related to U.S. and Brazilian sugarcane. In D. Pimentel (Ed.), Biofuels, solar and wind as renewable energy systems: benefits and risks (pp. 357-371). Dordrecht: Springer.

Pimentel, D., \& Patzek, T. (2008b). Ethanol production using corn, switchgrass and wood; biodiesel production using soybean. In D. Pimentel (Ed.), Biofuels, solar and wind as renewable energy systems: benefits and risks (pp. 373-394). Dordrecht: Springer. 